\title{
IKHTIAR MAHASISWA KKN STIBA MAKASSAR DALAM PEMBENTUKAN AKHLAK QUR'ANI MASYARAKAT DESA BALASSUKA KABUPATEN GOWA
}

\author{
Rachmat bin Badani Tempo \\ Sekolah Tinggi Ilmu Islam dan Bahasa Arab (STIBA) Makassar \\ rachmatbadani@stiba.ac.id \\ Khaerul Aqbar \\ Sekolah Tinggi Ilmu Islam dan Bahasa Arab (STIBA) Makassar \\ khaerul@stiba.ac.id
}

\section{Keywords : \\ Morality, Koran, Islamic Program}

\begin{abstract}
Balassuka Village is a village located in the Tombolo Pao District in the eastern part of Gowa Regency with a distance of around $88 \mathrm{~km}$ from the city of Sungguminasa, and a distance of $15 \mathrm{~km}$ from the capital district with a total area of approximately $29 \mathrm{~km} 2$. The village with its various problems in the economic, social, educational, health, religious and cultural fields is in need for problem solving and for village development program. The objective of STIBA Makassar Community Service Program (KKN) in Balassuka Village was to implement higher education tri dharma on the pillar of community service. The method of community service (PkM) implementation was started by conducting a field survey using an independently-made instrument, and afterwards an SOAR analysis was performed for the purposes of preparing the KKN programs. $K K N$ programs were generally divided into three those were the Koran education program, training, and community development. The Koran Education Programs were TK/ TPA, Dirosa (Koran Learning Program for Adult), Tahsinul Qira'ah, and discourse of the book Qawaid Qur'aniyah. Training programs included funeral arrangement training. Community development Program included Friday sermon, Taklim for youth and common people, brief Islamic speech every Magrib; Friday for worship; majlis taklim; and coaching for young mosque caretakers. The results of KKN activities show that the community and local government are very enthusiastic and grateful for the benefits they obtained from the implementation of KKN students' work programs in Balassuka Village. In terms of knowledge, the community has experienced the development of Islamic insight. In terms of skills a change is seen in the recitation of makhraj and tajweed in reading the Koran. In terms of affection, the community begins to realize and be enthusiastic in performing worship that is based on proper and correct religious knowledge.
\end{abstract}

Kata kunci :
Akhlak, Al-Quran, Program
Islam

Kata kunci : Islam

\footnotetext{
Desa Balassuka adalah suatu desa yang terletak di Kecamatan Tombolo Pao bagian Timur Kabupaten Gowa dengan jarak \pm 88 km dari kota Sungguminasa, dan berjarak $15 \mathrm{~km}$ dari Ibu Kota Kecamatan dengan Luas wilayah keseluruhannya adalah \pm 29 km2. Desa tersebut dengan berbagai problematikanya di bidang ekonomi, sosial, pendidikan, kesehatan, agama dan budaya diperlukan
} 
WAHATUL MUJTAMA': Jurnal Pengabdian Masyarakat

Vol. 01, No. 1 (2020) : Hal. 90-115

Website: https://journal.stiba.ac.id

pemecahan masalah dan program pengembangan desa. Tujuan dari KKN STIBA Makassar di Desa Balassuka adalah untuk mengamalkan tri dharma perguruan tinggi pada pilar pengabdian masyarakat. Metode pelaksanaan pengabdian masyarakat (PkM) adalah dimulai dengan melakukan survei lapangan dengan menggunakan instrumen mandiri, dan setelahnya dilakukan analisis SOAR untuk keperluan penyusunan program KKN. Adapun program KKN secara umum terbagi tiga yaitu program pendidikan al-Qur'an, pelatihan, dan pembinaan masyarakat. Program Pendidikan Al-Qur'an, di antranya TK/TPA; DIROSA (Pendidikan al-Qur'an Orang Dewasa); Tahsinul Qira'ah; dan Kajian Kitab Qawaid Qur'aniyah. Program Pelatihan, di antaranya: Pelatihan Penyelenggaraan Jenazah dan Pelatihan Mengajar Dirosa. Program Pembinaan Masyarakat, di antaranya: Khutbah Jum'at; Taklim Remaja dan Umum; Kultum Maghrib; Jum'at Ibadah; Majelis Taklim; dan Pembinaan Remaja Masjid. Hasil kegiatan KKN menunjukkan bahwa masyarakat dan pemerintah setempat sangat antusias dan berterima kasih atas manfaat yang diperoleh dari pelaksanaan program-program kerja mahasiswa KKN di Desa Balassuka. Dari sisi pengetahuan, masyarakat mengalami perkembangan wawasan keislaman. Dari sisi keterampilan perubahan dirasakan pada pelafalan makhraj dan tajwid dalam pembacaan al-Qur'an. Dari sisi afeksi, masyarakat mulai sadar dan bersemangat dalam melaksanakan ibadah yang didasari oleh ilmu agama yang baik dan benar. 


\section{PENDAHULUAN}

\section{Profil Desa Balassuka}

Secara geografis wilayah Desa Balassuka merupakan salh satu dari 9 Desa/Kelurahan di wilayah Kecamatan Tombolopao, Kabupaten Gowa, dilihat dari beberapa aspek tinjauan meliputi: Iklim, Tipologi, Orbitasi dan Batas Desa. Rinciannya sebagai berikut:

1. Iklim - Curah Hujan: 100 hari s.d. 250 hari; Jumlah bulan Hujan: 3 s.d. 8 Bulan; Suhu rata-rata harian: $20^{\circ}$ s.d. $30^{\circ} \mathrm{C}$; Tinggi Tempat: 600-950 mdpl; dan Bentang Wilayah: Berbukit.

2. Tipologi - Desa Kepulauan: Tidak; Desa Pantai/Pesisir: Tidak; Desa Sekitar Hutan: Ya; Desa Terisolir : Tidak; dan Desa Perbatasan dengan Kabupaten Lain: Ya.

3. Orbitrasi - Berada di Ibu Kota Kecamatan: Tidak; Jarak ke Ibu Kota Kecamatan: 15 km; Lama tempuh ke Ibu Kota Kecamatan: 40 Menit; Kendaraan umum ke Ibu Kota Kecamatan: Mobil dan Motor; Jarak ke Ibu Kota Kabupaten Gowa: 88 km; Lama tempuh ke Ibu Kota Kabupaten : 3 Jam; dan Kendaraan umum ke Ibu Kota Kabupaten: Mobil dan Motor.

4. Batas Desa - Sebelah Utara: Desa Tabbinjai; Sebelah Timur: Kelurahan Tasillilu, Kab. Sinjai; Sebelah Barat: Desa Mamampang; Sebelah Selatan: Desa Tonasa.

Adapun Luas Daerah Administrasi $\left(\mathrm{Km}^{2}\right)$ Menurut Dusun di Desa Balassuka dapat dilihat pada tabel berikut ini:

\begin{tabular}{ccc}
\hline No. & Dusun & Luas Wilayah \\
\hline 1 & Sapohiring & $3014088 \mathrm{~m} 2$ \\
\hline 2 & Benga & $2268682 \mathrm{~m} 2$ \\
\hline 3 & Lembang Teko & $1731498 \mathrm{~m} 2$ \\
\hline 4 & Sapiribborong & $973353 \mathrm{~m} 2$ \\
\hline 5 & Palulung & $566434 \mathrm{~m} 2$ \\
\hline & Jumlah & $8554055 \mathrm{~m} 2$ \\
\hline
\end{tabular}

Desa Balassuka adalah suatu desa yang terletak di Kecamatan Tombolo Pao bagian Timur Kabupaten Gowa dengan jarak \pm 88 km dari kota Sungguminasa, dan berjarak $15 \mathrm{~km}$ dari Ibu Kota Kecamatan. Luas wilayahnya adalah $\pm 29 \mathrm{~km} 2$ dengan batas-batas wilayah yaitu: Sebelah Utara: Desa Tabbinjai; Sebelah Timur: Kel. Tasillilu, Kec. Sinjai Barat, Kab. Sinjai; Sebelah Barat: Desa Mamampang; Sebelah Selatan: Desa Tonasa. Adapun Pusat Pemerintahan Desa Balassuka terletak di Dusun Lembang Teko. Secara Administrasi, Desa Balassuka membawahi 5 wilayah Dusun, dan setiap Dusun dibagi beberapa RW dan RT yaitu: Dusun Sapohiring, terdiri dari 4 RW dan 9 RT; Dusun Benga, terdiri dari 3 RW dan 6 RT; Dusun 
Lembangteko, terdiri dari 3 RW dan 7 RT; Dusun Sapiribborong, terdiri dari 3 RW dan 7 RT; dan Dusun Palulung, terdiri dari 2 RW dan 4 RT.

Sejarah Desa Balassuka - Pada tahun 1990 sampai dengan 1998, M. Yusuf AM memimpin desa Balassuka sebagai pejabat yang ditunjuk, nanti pada pemilihan secara langsung yang pertama kalinya pada tahun 1998, Bapak M. Yusuf AM kembali mencalonkan diri bersaing dengan Bapak Syaharuddin dan Bapak M. Yusuf AM kembali terpilih dan memimpin desa Balassuka sampai pemilihan berikutnya pada tahun 2003 .

Pada pemilihan ini Bapak M. Yusuf AM kembali dicalonkan dan bersaing dengan Drs. Abdul Latif dan Abdul Malik, S.Sos.I., salah seorang tokoh masyarakat/tokoh pendidikan di desa Balassuka. Seiring dengan keluarnya peraturan daerah tahun 2008 tentang aturan jabatan kepala desa berlaku selama dua periode dan dalam satu periode dijabat selama enam tahun maka pada pemilihan kepala desa yang ketiga di desa Balassuka, Bapak M. Yusuf AM kembali dicalonkan dan bersaing dengan Abdul Malik.

Dari struktur dan proses kepemimpinan kepala desa Balassuka di atas, menandakan bahwa masyarakat desa Balassuka sudah sangat memahami mekanisme politik yang demokratis. Pola kepemimpinan di desa Balassuka dalam pengambilan keputusan berada ditangan kepala desa, dengan persetujuan Badan Perwakilan Desa (BPD) namun semuanya dilakukan dengan mekanisme yang melibatkan pertimbangan dari masyarakat melalui musyawarah mufakat.

Potensi Lokal Desa Balassuka - Desa Balassuka memiliki potensi yang sangat besar terutama dari sumber daya alam maupun sumber daya manusianya. Sampai saat ini potensi sumber daya belum benar-benar optimal diberdayakan. Hal ini terjadi karena belum teratasinya hambatan-hambatan yang ada. Berikut beberapa potensi yang ada di desa Balassuka: Hutan lindung: 0 ha; Hutan rakyat : 13 ha; Sawah : 501 ha; Ladang: 1467,3 ha; Lahan pemukiman/perumahan: 181 ha; Lahan pengembalaan/tidur: 737,7 ha; Sungai: 6 buah; Hasil pertanian: Padi, Jagung, Cabe, Kol, Tomat, dll.; Hasil perkebunan: Kakao, Kopi, Cengkeh, Pisang, dll.; Tambang Gol C: Sertu, Batu Kali/Gunung; Jalan Aspal: 8 km; Jalan Perkerasan: 7 $\mathrm{km}$; Jalan Tanah: $12 \mathrm{~km}$.

Secara umum mata pencaharian masyarakat desa balassuka dapat teridentifikasi dalam beberapa bidang seperti petani, buruh tani, karyawan swasta, pedagang, wirausaha/ jualan, PNS/ TNI/POLRI, pensiunan, biro jasa, pertukangan, dan sopir. Berdasarkan tabulasi data teridentifikasi di Desa Balassuka jumlah penduduk yang mempunyai mata pencaharian 35,086\% dari jumlah penduduk secara keseluruhan. Kehidupannya tergantung disektor: PNS 0,29\%, buruh tani $12,83 \%$, petani $19,13 \%$, dan wiraswasta/jualan $0,35 \%$ dari total jumlah penduduk. Dengan demikian, dari data tersebut menunjukkan bahwa masyarakat di desa Balassuka secara umum atau sekitar $31,96 \%$ hidupnya bergantung di sektor 
pertanian. Namun masih banyak penduduk yang keluar desa atau ke kota mengadu nasib untuk mencari pekerjaan lain.

Berdasarkan data administrasi Pemerintahan Desa Balassuka tahun 2019, jumlah penduduk yang tercatat secara administrasi adalah 3290 jiwa, yang terdiri dari 1196 laki-laki dan 1221 perempuan. Jumlah kepala keluarga yang tercatat secara administrasi adalah 842 kepala keluarga.

Bidang Pendidikan - Pendidikan adalah salah satu hal penting dalam memajukan tingkat kesejahteraan pada umumnya dan tingkat perkonomian pada khususnya. Dengan tingkat pendidikan yang tinggi maka kan mendongkrak tingkat kecakapan. Tingkat kecakapan juga akan mendorong tumbuhnya keterampilan kewirausahhan dan pada giliranya akan mendorong munculnya lapangan pekerjaan baru. Dengan demikian, akan membantu program pemerintaah untuk pembukaan lapangan kerja baru guna mangatasi pengangguran. Pendidikan biasanya akan dapat mempertajam sistematika fikir atau pola pikir individu, selain itu akan mempermudah menerima informasi yang lebih maju. Sekolah-sekolah yang terdapat di Desa Balassuka: TK Aisyah Lembang Teko; TK Turisida; SD Inpres Bocci; SD Inpres Palempang; SDN Lembang Teko; MI Sapiribborong; MI Maarif Palulung; MI Al-Mujahidin Lebbasa; MTs Muhammadiyah Balassuka; MA Muhammadiyah Balassuka; SPAS Palulung; dan RA Tunas Bangsa Benga.

Dengan melihat jumlah penduduk tamat sekolah berdasarkan jenjang pendidikan yang diurai disetiap lingkungan mulai dari yang tidak tamat sekolah atau yang tidak memiliki pendidkan sampai pada yang tamat pada perguruan tinggi dapatlah disimpulkan bahwa taraf pendidikan masyarakat di Desa Balassuka cukup tinggi, dari 3307 jiwa yaitu 808 jiwa yang mampu menamatkan sekolahnya sampai pada tingkat SD yang berarti $24,43 \%$ dari jumlah penduduk. Sementara yang mampu menamatkan sekolahnya sampai pada tingkat SMP yang menempati urutan kedua dengan jumlah tamatan sebanyak 253 jiwa atau 7,65\% dari jumlah penduduk, selanjutnya yang menempati urutan ketiga adalah SMA dengan 212 jiwa atau $6,41 \%$ dari jumlah penduduk, sedangkan yang mampu menyelesaikan sampai pada perguruan tinggi sebanyak 94 orang atau sekirtar 2,84\% dari jumlah penduduk Desa Balassuka.

Bidang Ekonomi - Desa Balassuka memiliki organisasi masyarakat yang bergerak di bidang ekonomi/finansial, di antaranya: Kelompok SPP 2 Klp; Kelompok Tani 6 Klp; Kelompok Tani ternak 3 Klp; Kelompok Arisan 1 Klp; Koperasi Wana Lestari; Usaha Tukang Jahit 1 unit; Kelompok Usaha Mandiri KUM 1 Klp; Koperasi “AMAL” Sejahtera (Pengecer Pupuk Bersubsidi) 1 Klp.

Bidang Sosial Budaya - Desa Balassuka memiliki organisasi masyarakat yang berbasis sosial budaya, di antaranya: Kelompok Remaja Masjid 3 Klp; Kelompok Majelis Taklim 1 Klp; Ranting Muhammadiyah; Ranting Aisyiah; Ranting IPM; dan Kelompok Seni Kasidah Rebana 3 Klp. Desa Balassuka memiliki 
beberapa budaya di masyarakat, di antaranya: Budaya Assattu (Gotong Royong); Akronda (Jaga Malam); Akkammisi (Perempuan); dan Attompolo (Akikah). Tempat Ibadah yang terdapat di Desa Balassuka: Masjid Nurul Yaqin Sapohiring; Masjid Nurul Iman Bentengia; Masjid Baiturrahman Benga; Masjid Nurul Amin Lembang Teko; Masjid Babussalam Lebbasa; Masjid Nurul Huda Palulung; Masjid Baitussalam Sapiribborong; Masjid Al-Amin Padakka; Masjid Babul Jannah Bongki; Masjid Miftahul Khair; Masjid Jabal Nur Palempang; Masjid Nurul Jihad Palempang; Masjid Jabal Khair Bulu' Lohe; Mushallah Al-Muhajirin Bocci; dan Mushallah Jabal Nur.

Sarana Kesehatan - Terdapat beberapa Posyandu di Desa Balassuka yaitu Posyandu Sapohiring; Posyandu Benga; Posyandu Lembang Teko; Posyandu Palulung; dan Posyandu Sapiribborong.

\section{Problematika di Desa Ballasuka}

Persoalan Ekonomi - Mayoritas masyarakat adalah petani dan buruh tani, Tingkat kemampuan ekonomi masyarakat secara umum menengah ke bawah, dan Sistem pertanian masih tradisional dengan bergantung pada alam atau curah hujan. Dengan demikian, asumsinya adalah masyarakat memiliki keterbasan dalam memperoleh modal usaha menghambat masyarakat untuk mengembangkan usaha dagang atau pertanian mereka, Kurangnya keterampilan tambahan menjadikan masyarakat banyak berpatokan pada usaha pertanian dan perkebunan, dan SDM masyarakat dalam mengelola pertanian dan perkebunan masih sangat rendah disebabkan kurangnya pembinaan dan penyuluhan pertanian.

Persoalan Sosial dan Pendidikan -Kurangnya saran pendidikan dan tenaga pengajar terutama di sekolah-sekolah terpencil sehingga kalah bersaing ilmu pengetahuannya dengan daerah lain; Masih kurangnya kesadaran masyarakat akan pentingnya pendidikan sehingga banyak anak putus sekolah; Mayoritas penduduk desa Balassuka masih berpendidikan rendah, sehingga kurang mampu bersaing dalam memeroleh pekerjaan maupun membuka/ menciptakan lapangan pekerjaan; Masih tersebar di tiap RW warga masyarakat yang buta huruf; Tidak memadainya sarana akses jalan. Masih kurangnya jalan usaha tani sehingga masyarakat tidak maksimal dalam mengolah lahan. Asumsi yang dapat ditarik bahwa SDM dan manajemen yang lemah menyebabkan sebagian besar sekolah di desa terbelakang dalam hal kualitas siswa; Sebagian masyarakat belum memahami pentingnya pendidikan dan lebih mengutamakan berladang atau berkebun; Pendidikan yang rendah menyebabkan masyarakat terbelakang dalam persaingan di dunia kerja; dan Sebagian wilayah pertanian dan perkebunan yang berada didaerah perbukitan atau yang jauh dari akses jalan masih kesulitan dalam mengelola lahannya dan mengangkut hasil panen karena jarak yang cukup jauh. 
Persoalan Agama dan Budaya -Sebagian besar masjid belum terpakai untuk lima waktu shalat, khususnya di jam-jam berladang; Kurangnya keteladanan dari Imam-Imam dusun yang telah ditunjuk, khususnya dalam hal shalat lima waktu; Muballigh untuk khutbah dan pemateri pengajian masih minim jumlah; Pengurus remaja masjid disebagian masjid kurang aktif; Budaya masyarakat Desa Balassuka banyak dipengaruhi oleh budaya Bugis - Makassar; Pantang meninggalkan rumah ketika makanan telah dihidangkan; dan Penggunaan rokok dalam tradisi masyarakat. Asumsinya adalah Kesibukan berladang disiang hari menyebabkan masyarakat tidak shalat berjamaah di masjid; Evaluasi dan kontroling imam desa masih lemah sehingga banyak imam dusun yang belum menjalankan tupoksinya dengan baik; Jumlah muballigh atau da'i masih kurang karena sebagian besar masyarakat yang melanjutkan pendidikannya ke tingkat perguruan tinggi mengambil jurusan umum dan bukan agama; Setelah pembentukan Pengurus remaja masjid oleh masyarakat, tindak lanjut berupa pengontrolan kegiatan atau evaluasi kinerja pengurus tidak dilakukan sehingga remaja masjid kurang aktfi berkegiatan; dan budaya berunsur kesyirikan dalam tradisi Bugis - Makassar yang masih dijaga dan dipelihara menandakan bahwa pemahaman keislaman masyarakat masih sangat minim.

\section{SOAR Analysis untuk Penyusunan Program Kegiatan KKN}

Strengths: Kerja sama tim mahasiswa KKN cukup solid; Seluruh mahasiswa KKN memiliki kapasitas keilmuan yang cukup; Dukungan dari pihak STIBA dan desa; Pengalaman organisasi sebagian mahasiswa KKN sangat membantu terealisasinya program kerja; Dukungan dana dari donator yang memadai; dan Posko KKN yang strategis berada dilingkup sekolah dan pesantren

Opportunities: Sebagian dari populasi penduduk adalah remaja dan anakanak; Luasnya Lahan untuk pembangunan dan pemberdayaan desa; Terdapat banyak kelompok tani; Terdapat banyak majelis taklim; Kuatnya pengaruh keagamaan organisasi muhammadiyah; Kebutuhan masyarakat dengan guru ngaji yang tinggi; Masyarakat sangat terbuka dengan pendatang; dan Kepala desa adalah tokoh muhammadiyah setempat.

Aspirations: Remaja masjid perlu dibina dan diberdayakan untuk kegiatankegiatan masjid; Masyarakat butuh pembinan tentang pentingnya berislam secara benar; Pemuda desa kurang diperhatikan khususnya tentang pentingnya keagamaan dan pendidikan mereka; Pembinaan manajemen TPQ/TPA sangat dibutuhkan; Masyarakat belum kenal pengobatan sunnah; Ada lokasi wisata yang belum dikelola dengan baik oleh pemerintah desa.

Result: Remaja masjid aktif meramaikan masjid dengan shalat lima waktu dan kegiatan-kegiatan keagamaan lainnya; Terwujudnya masyarakat yang agamis; Pemuda terberdayakan dengan kegiatan-kegiatan bermanfaat; Terwujudnya 
manajemen TPA/TPQ yang professional; Masyarakat meninggalkan pengobatan Sihir dan kembali kepada pengobatan sunnah; Wisata desa bias terekspos keluar.

Berdasarkan uraian tentang profil desa, problematika desa, dan analisis singkat SOAR tentang Desa Balassuka, maka pelaksanaan KKN STIBA Makassar Angkatan ketiga tahun 2020 di Desa Balassuka Kecamatan Tombolo Pao Kabupaten Gowa yang dimulai pada tanggal 6 Januari 2020 sampai dengan 24 Februari 2020 dirumuskan tiga program kerja pokok beserta rinciannya. Adapun daftar Program Kerja adalah sebagai berikut

1. Program Pendidikan Al-Qur'an, di antranya TK/TPA; DIROSA (Pendidikan alQur'an Orang Dewasa); Tahsinul Qira'ah; dan Kajian Kitab Qawaid Qur'aniyah.

2. Program Pelatihan, di antaranya: Pelatihan Penyelenggaraan Jenazah dan Pelatihan Mengajar Dirosa.

3. Program Pembinaan Masyarakat, di antaranya: Khutbah Jum'at; Taklim Remaja dan Umum; Kultum Maghrib; Jum'at Ibadah; Majelis Taklim; dan Pembinaan Remaja Masjid.

Sasaran kegiatan KKN di Desa Balassuka merupakan Masyarakat setempat, termasuk kegiatan masyarakat yang ada didalamnya. Pada artikel pengabdian masyarakat ini, tampak pula sejalan dengan hasil-hasil PkM yang telah dilakukan sebelumnya, di antaranya:

1. Hasil penelitian Perdana, dkk., menunjukan bahwa terdapat hubungan yang signifikan antara pengaruh KKN terhadap keterampilan social mahasiswa, artinya semakin tinggi tingkat interaksi yang terjadi selama KKN akan mempengaruhi keterampilan sosial pada mahasiswa. ${ }^{1}$

2. Program kegiatan KKN oleh Mulasari, dkk., dilakukan dengan metode penyuluhan dan pelatihan peningkatan usaha kecil dan perintisan unit usaha dengan memanfaatkan potensi lokal telah berhasil memberikan tambahan pengetahuan dan keterampilan kepada masyarakat untuk pengembangan unit usaha dengan memanfaatkan potensi lokal. ${ }^{2}$

3. Hasil penelitian oleh Fajri diketahui bahwa: program kegiatan KKN secara kelompok telah berhasil melaksanakan gotong royong bersama masyarakat Gampong untuk memperbaiki fasilitas umum dan sarana umum yang ada di Gampong. $^{3}$

\footnotetext{
${ }^{1}$ Perdana, A., Holilulloh, M., Holilulloh, M. S., \& Nurmalisa, Y. Pengaruh Pelaksanaan Kuliah Kerja Nyata Terhadap Keterampilan Sosial Mahasiswa Program Studi PPKN. Jurnal Kultur Demokrasi, Vol.1, No.7. (2013)

${ }^{2}$ Mulasari, S. A., Fatihah, A. N., \& Setiawan, A. Upaya Penanggulangan Rentenir Oleh Kuliah Kerja Nyata Universitas Ahmad Dahlan di Dusun Klepu, Nglegi, Patuk, Gunungkidul, Di. Yogyakarta 2018. Jurnal Pemberdayaan: Publikasi Hasil Pengabdian Kepada Masyarakat, Vol.2, No.3 (2019): 479-486.

${ }^{3}$ Fajri, Z. Manfaat Pelaksanaan Program Kegiatan Kuliah Kerja Nyata (KKN) Mahasiswa (Suatu Penelitian di Kecamatan Meurah Dua Pidie Jaya). Etd Unsyiah 2015.
} 
4. Hasil dari pemberdayaan masyarakat oleh Gustina yang dilakukan melalui kegiatan KKN Mahasiswa Universitas Bengkulu periode 86 Tahun 2018 di Desa Tebat Monok terlah berhasil memenuhi kebutuhan dasar masyarakat desa Tebat Monok di bidang kewirausahaan melalui kegiatan sosialisasi dan pelatihan sesuai dengan kebutuhan masyarakat. ${ }^{4}$

Atas hasil PkM di atas, maka pada PkM ini memiliki kesamaan dari sisi pemberdayaan masyarakat melalui aktivitas pelaksanaan program KKN dengan metode penyuluhan, pembinaan dan pelatihan. Kesamaan juga tampak dari analisis kebutuhan masyarakat sebelum aksi KKN di masyarakat. Namun, kekhasan dalam PkM ini memakai analisis SOAR sederhana. Perbedaan lainnya juga dalam PkM berwujud KKN ini adalah penekanan programnya pada penanaman ilmu keislaman, pengembangan keterampilan baca tulis al-Qur'an, dan pengembangan minat dan bakat anak-anak dan remaja dalam bidang dakwah. Hal demikian lantaran corak STIBA Makassar yang konsern pada pengembangan studi Islam dan pengkaderan ulama dalam kurikulum pendidikannya.

\section{PEMBAHASAN}

\section{Seminar Program Kerja KKN}

Tujuan dan manfaat: memperkenalkan masyarakat dengan programprogram KKN STIBA sekaligus mendengarkan usulan program dari masyarakat. Memberikan peluang untuk mahasiswa KKN STIBA agar lebih dikenal oleh tokohtokoh masyarakat dan masyarakat setempat diawal-awal masa KKN. Menurut Indrawan, dkk., ihwal silaturahmi dalam konteks manajemen organisasi pendidikan Islam mengemukakan bahwa dalam silaturahmi terdapat hikmah yang besar diantaranya mempererat tali persaudaraan antar sesama, membuka pintu rezki, saling mengenal dan memperluas persaudaraan, menambah ilmu dan hikmah hidup, menambah empati dan menjauhi sikap egois. ${ }^{5}$ Hal tersebut sejalan dengan harapan dalam pelaksanaan seminar program kerja ini.

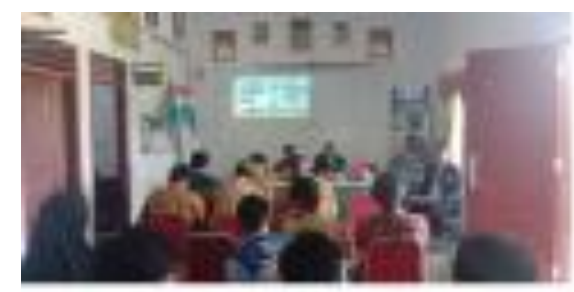

Gambar 1.1. Seminar Program Kerja

\footnotetext{
${ }^{4}$ Gustina, D., Adbullah, I., \& Sofino, S. Pemberdayaan Masyarakat Melalui Kegiatan Kuliah Kerja Nyata (Kkn) Mahasiswa Universitas Bengkulu Periode 86 Tahun 2018 Di Desa Tebat Monok Kabupaten Kepahiang. Journal Of Lifelong Learning, Vol.2, No.1 2019

${ }^{5}$ Indrawan, I., Sukri, A., \& US, K. A. Silaturahmi Pemimpin Terhadap Bawahan Dalam Sistem Manajemen Pendidikan Islam. Jurnal Al-Afkar, Vol.7, No.1, 2019
} 
Rencana pelaksanaan kegiatan dan waktu pelaksanaan: Aula Kantor Desa Balassuka pada hari Selasa, 14 Januari 2020 Pukul 09.00 - 12.00. Sasaran adalah Pemerintah Desa, Tokoh Masyarakat, Tokoh Pemuda dan Pemuka Agama setempat. Target Jumlah Peserta 30 Orang. Adapun ancangan estimasi biaya sebesar Rp. 100.000,- untuk keperluan Konsumsi Tamu Undangan. LangkahLangkah Kegiatan: Musyawarah Persiapan Seminar, Menyusun Program Kerja berdasarkan hasil observasi dan komunikasi dengan masyarakat, dan Sosialisasi Program Kerja di kantor desa. Faktor pendukung kegiatan ialah Pihak Pemerintah memberikan fasilitas yang memadai dalam kegiatan Seminar Program Kerja.

Hasil kegiatan: kegiatan berlangsung lancar dan seluruh proker telah dijelaskan dengan baik serta mendapat sambutan yang hangat dari tokoh-tokoh masyarakat. Hambatan yang ditemui yaitu Acara terlambat dimulai karena keterlambatan mahasiswa dan tamu undangan, dan juga Beberapa tokoh masyarakat tidak hadir di tempat. Pelajaran ke depan adalah Lebih disiplin lagi dalam berkegiatan, dan juga Undangan yang perlu disebar jauh-jauh hari sebelum acara. Pengalaman menarik ialah Menyampaikan program ke Masyarakat Desa Balassuka, dan Masyarakat sangat tertarik dengan program-program yang telah dipaparkan khususnya Bebas Buta Huruf (DIROSA) dan Khutbah Jum'at.

\section{Pengajian Remaja}

Tujuan dan manfaat: pembinaan langsung untuk remaja putra dan putri desa Balassuka, khususnya bagi anggota Ikatan Pelajar Muhammadiyah yang merupakan organisasi remaja dengan peran strategis diantara remaja setempat. Menambah wawasan keagamaan remaja dan semakin mendekatkan mereka dengan masjid. Ihwal pengajian remaja, melalui hasil penelitiannya menunjukkan bahwa pembinaan Keagamaan Islam bagi remaja di Kelurahan Tanah Sirah Piai Nan XX berhasil menunjukkan respon yang baik dari masyarakat dan dianggap sebagai cara yang efektif untuk menyiapkan generasi Islam. ${ }^{6}$

Rencana pelaksanaan kegiatan dan waktu pelaksanaan: Masjid Nurul Yaqin Dusun Sapohiring, Setiap hari Selasa dan Ahad, Setelah Shalat Ashar sampai menjelang Maghrib. Target peserta Remaja Desa Balassuka. Sumber pendanaan berasal dari Donasi dan Pribadi. Langkah-langkah kegiatan: Sosialisasi Pelaksanaan Kajian Remaja di Masjid Masjid Nurul Yaqin, Musyawarah Kajian Remaja, Pembuatan Pamflet, Pengumuman Ta'lim di Masjid, Terlaksananya Ta'lim Rutin sekali dalam satu pecan ba'da ashar. Faktor pendukung kegiatan ialah

${ }^{6}$ Iswadi, I. Penguatan Nilai Keagamaan Bagi Kelompok Pengajian Remaja di Kelurahan Tanah Sirah Piai Nan XX. Alfuad: Jurnal Sosial Keagamaan, Vol.3, No.2, 2019: h.76-84. 
adanya perizinan dari pengurus masjid untuk mengisi kajian remaja, dan Adanya kerjasama dengan IPM.

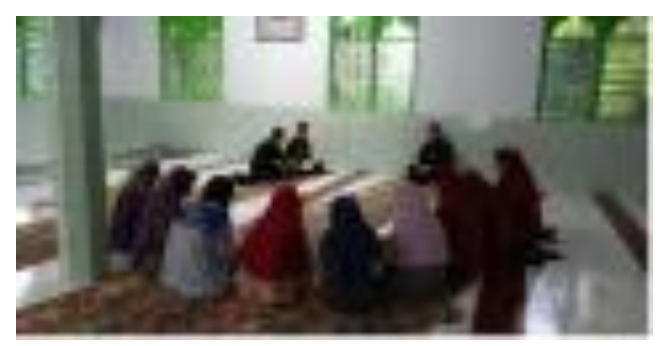

Gambar 1.2. Pengajian Remaja

Hasil kegiatan: kegiatan dilaksanakan di Masjid Nurul Yaqin Sapohiring setiap hari selasa dan ahad sore dengan kisaran peserta kurang lebih 7 - 20 orang setiap pengajian. Hambatan yang dijumpai adalah Informasi pengajian yang belum tersampaikan ke seluruh remaja desa, Antusias remaja yang kadang naik turun, dan Sebagian besar tidak memiliki kendaraan pribadi sedangkan jarak rumah mereka cukup jauh. Langkah solutif adalah memanfaatkan media social untuk penyebar luasan informasi pengajian dan motivasi dan apresiasi dari pemateri. Pengalaman menarik yaitu banyaknya pertanyaan dari remaja yang membuat kami harus semakin banyak belajar.

\section{Pengajian Kitab}

Tujuan dan manfaat: sebagai sarana berbagi ilmu keagamaan dan memperkenalkan kepada masyarakat kitab-kitab karangan ulama yang berbahasa arab. memberikan wawasan tambahan tentang ilmu agama kepada masyarakat sekaligus peluang berdiskusi tentang masalah yang banyak berkembang di desa. Sejalan dengan ini, melalui penelitian Sulandri, dkk., menujukkan bahwa Lansia yang mengikuti pengajian tidak hanya mendapatkan manfaat spiritual (mendapatkan ilmu baru terkait pengetahuan agama) tetapi juga manfaat sosial (mempererat tali silahturami, menambah pertemanan, dan berbagi pengetahuan) serta manfaat psikologis (perasaan senang). ${ }^{7}$ Rencana pelaksanaan kegiatan dan Waktu pelaksanaan: Setiap Malam Ahad, Selama masa KKN. Target dan jumlah peserta ialah Seluruh masyarakat sebanyak 20 - 30 Orang. Sumber dana barasal dari pribadi dan donasi.

${ }^{7}$ Sulandari, S., Wijayanti, M., \& Pornamasari, R. D. Keterlibatan Lansia dalam Pengajian: Manfaat Spiritual, Sosial, dan Psikologis. Indigenous: Jurnal Ilmiah Psikologi, Vol.1, No.2, 2017 


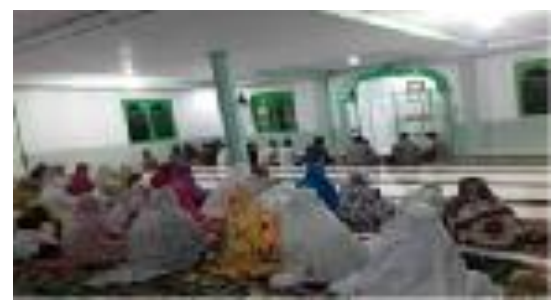

Gambar 1.3. Pengajian Kitab

Langkah-langkah kegiatan: Musyawarah, Sosialisasi dengan masyarakat dan menyebarkan pamphlet melalui sosial media dan menyebar pamphlet di masjidmasjid, dan Kajian dilaksanakan ba'da magrib sampai isya. Faktor pendukung kegiatan ialah Pengurus masjid memberikan izin untuk mengadakan kajian tiap pekan, dan Kerjasama IPM dalam menyukseskan kajian tiap pekan.

Hasil kegiatan: Berlagsung sekali dalam sepekan secara berkesinambungan yang diisi langsung oleh mahasiswa KKN STIBA. Hambatan yang dijumpai ialah Mayoritas peserta adalah yang bermukim disekitar masjid, dan Jarak yang jauh dari dusun warga lain. Tindakan solutif berupa Menyebarluaskan info pengajian melalui media social yanga ada, dan Penanaman nilai keislaman bagi masyarakat yang tidak ikut pengajian dilakukan di sela-sela pengajaran Al Qur'an. Pengalaman menarik yang didapatkan ialah Masyarakat sangat semangat karena pertama kali ada mahasiswa KKN membawkan kajian menggunakan kitab Bahasa Arab.

\section{Kultum Maghrib}

Tujuan dan manfaat: Sebagai bentuk latihan berbicara di depan umum bagi mahasiswa dan berbagi motivasi serta semangat berislam kepada warga desa. Hal ini koheren dengan penelitian yang dilakukan oleh Nurhayati ihwal hubungan kultum yang menyatakan bahwa terdapat hubungan yang signifikan antara tanggapan masyarakat terhadap kultum ba'da Subuh dengan motivasi mereka dalam mengikuti shalat berjamaah di masjid. ${ }^{8}$ Selain itu, tujuan dari kultum magribisya ini adalah untuk meningkatkan kemampuan mahasiswa dalam menyampaikan nasehatnya dengan waktu yang singkat di depan orang banyak.

Rencana pelaksanaan kegiatan dan waktu pelaksanaan: mushallah Jabal Nur Pesantren Darul Arqam Balassuka setiap Ba'da Maghrib. Sasaran adalah warga setempat dan target jumlah peserta 50 Orang. Sumber dana berasal dari Pribadi dan Donasi. Langkah-langkah kegiatan: Permintaan Pimpinan Pondok kultum, Musyawarah penentuan jadwal Qultum, dan Mahasiswa memberikan Qultum setelah sholat mahgrib. Faktor pendukung kegiatan ialah Pimpinan Pondok

\footnotetext{
${ }^{8}$ Nurhayati, S. Tanggapan masyarakat terhadap kultum ba'da subuh hubungannya dengan motivasi mereka dalam mengikuti shalat berjamaah di masjid: Penelitian di Masjid Jami Nurul Huda Cirabak RT 005 RW 002 Dusun Cibingbin Rajadesa Ciamis (Doctoral dissertation, UIN Sunan Gunung Djati Bandung, 2017).
} 
memberikan kesempatan Mahasiswa STIBA untuk memberi Kultum di mushallah dan antusias santri mendengarkan kultum.

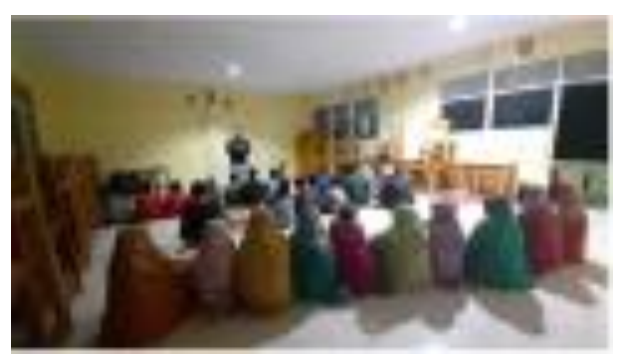

Gambar 1.4. Kultum Maghrib-Isya

Hasil kegiatan: kegiatan dilaksanakan dengan lancar dan mendapat respon yang baik dari warga pesantren Darul Arqam Balassuka, mahasiswa KKN jadi lebih terampil dan terbiasa berbicara memberikan kultum. Hambatan yang ditemui adalah jadwal kultum bertepatan jadwal mengajar Dirosa dan Persiapan materi yang kurang. Tindakan solutif Mahasiswa yang berhalangan kultum digantikan oleh Koordes Balassuka dan Mempersiapkan materi lebih awal. Pengalaman menarik yang dijumpai ialah Santri sangat antusias mendengarkan materi kultum dari mahasiswa, dan Santri meminta materi kultum yang telah didengarkan.

\section{Majelis Taklim Ibu-Ibu}

Tujuan dan manfaat: memberikan pemahaman tentang Fiqh Muslimah kepada masyarakat dari kalangan ibu-ibu serta memotivasi mereka untuk semangat dalam menjalankan aturan agama. Saran silaturahmi sekaligus berbagi pengetahuan keagamaan kepada ibu-ibu majelis taklim. Segayut dengannya melalui penelitian Jasmiana ihwal majelis taklim menunjukkan bahwa majelis taklim sebagai lembaga non formal yang ada ditengah-tengah masyarakat dapat memberikan konstribusi cukup besar bagi perkembangan pemahaman keagamaan masyarakat. ${ }^{9}$

Rencana pelaksanaan kegiatan dan Waktu pelaksanaan: Mengikuti permintaan dari Ibu-ibu Majelis Taklim dan tempat Menyesuaikan. Target dan jumlah peserta ialah Majelis Taklim Sedesa Balassuka dengan jumlah sebanyak 20 - 100 Orang. Sumber dana barasal dari pribadi dan donasi. Langkah-langkah kegiatan adalah Musyawarah Penentuan pemateri yang akan mengisi Majelis Taklim Ibu-Ibu, Komunikasi dengan Ibu Desa dan Ibu Imam Desa, dan Terlaksananya kegaitan Majelis Taklim Ibu-Ibu. Faktor pendukung kegitan ini yaitu adanya dukungan dari Ibu Desa untuk memberikan kesempatan mengisi taklim Ibu-Ibu.

${ }^{9}$ Dangnga, M. S. Peran Majelis Taklim Nurul Huda Dalam Peningkatan Pengamalan Keagamaan Masyarakat Kelurahan Palanro Kabupaten Barru. 


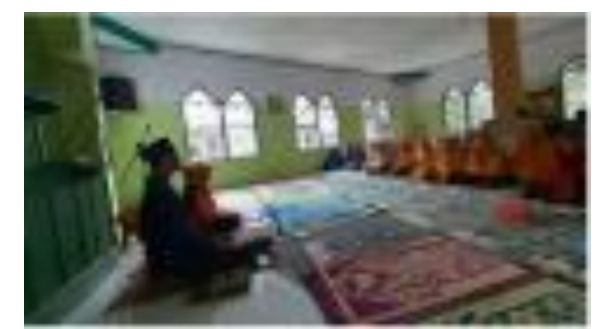

Gambar 1.5. Majelis Taklim Ibu-Ibu

Hasil kegiatan: Berlangsung lebih dari 4 kali selama masa KKN STIBA di Desa Balassuka di majelis taklim yang berbeda-beda. Hambatan yang dijumpai ialah Jarak yang cukup jauh dan Bertepatan dengan kegiatan lain. Tindakan solutif berupa Menggunakan kendaraan jemputan dan Pembagian waktu. Pengalaman menarik yang dijumpai dari kegiatan ini adalah Pertama kalinya mengisi taklim ibuibu.

\section{Jum'at Ibadah}

Tujuan dan manfaat: sebagai bentuk silaturahmi mahasiswa KKN dengan pemerintah Desa dan menindaklanjuti permintaan kepala desa untuk program rutin Kabupaten Gowa. Sarana silaturahmi dan sharing nasehat keagamaan kepada unsur perangkat pemerintah Desa Balassuka. Senada dengannya, ihwal program Jum'at Ibadah Kabupaten Gowa, melalui hasil penelitian Handayani mengemukakan bahwa aktivitas Program jum'at ibadah bertujuan dalam pembentukan Akhlak dan memberi makna ibadah terhadap perilaku serta kegiatan keseharian (amal atau muamalah) masyarakat melalui langkah-langkah penyajian materi program yang edukatif dan religius. ${ }^{10}$

Rencana pelaksanaan kegiatan dan Waktu pelaksanaan: Dua kali dalam sebulan, pada pekan pertama dan pekan terakhir yang bertempat di aula kantor Desa Balassuka. Target dan jumlah peserta ialah Aparat pemerintah Desa sebanyak 20 orang. Sumber dana barasal dari pribadi dan donasi.

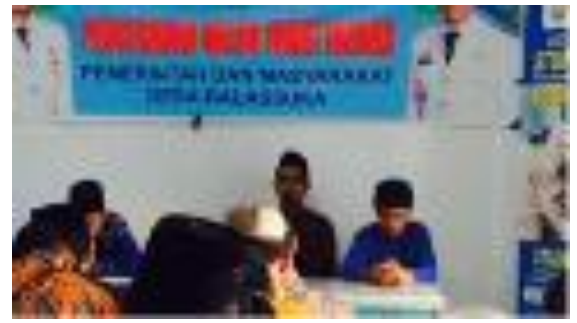

Gambar 1.6. Jumat Ibadah

\footnotetext{
${ }^{10}$ Handayani, H. Aktivitas Program Jum'at Ibadah dalam Pembentukan Akhlak Al-Karimah di Desa Mardekaya Kecamatan Bajeng Kabupaten Gowa (Doctoral dissertation, Universitas Islam Negeri Alauddin Makassar, 2017).
} 
Langkah-langkah kegiatan: Musyawarah Penentuan pemateri jum'at ibadah, dan Berangkat menuju lokasi Jum'at Ibadah. Faktor pendukung kegiatan ini ialah Kepala Desa memberikan kesempatan selama masa KKN untuk mengisi Jum'at Ibadah. Hasil kegiatan: Berlangsung dua kali dalam sebulan, pada pekan pertama dan pekan terakhir yang bertempat di aula kantor desa. Tidak ditemukan kendala dalam kegiatan ini. Pengalaman menarik yang dijumpai ialah Pertama kalinya mendapati kegiatan Jum'at Ibadah.

\section{Khutbah Jum'at}

Tujuan dan manfaat: membantu pemerintah desa dalam menyemarakkan pelaksanaan ibadah jum'at yang sering terkendala dengan kurangnya da'i dan khatib setiap jum'at. Mengingatkan masyarakat Desa Balassuka untuk bertaqwa kepada Allah, bersyukur kepada Allah dan meningkatkan skill bagi mahasiswa dalam berkhutbah. Implikasi yang diharapkan adalah sejalan dengan hasil penelitian yang dilakukan oleh Pambudi yang menyatakan bahwa kerutinan khutbah jumat yang dilakukan sangat berimbas pada perubahan perilaku keagamaan, memperbaiki kehidupan masyarakat, baik dalam lingkungan keluarga, teman bahkan lingkungan masyarakat. ${ }^{11}$ Rencana pelaksanaan kegiatan dan waktu pelaksanaan: di laksanakan di 12 Masjid Se-Desa Balassuka Setiap Hari Jum'at. Sumber dana atau operasional berasal dari pribadi dan donasi.

Langkah-langkah kegiatan: Musyawarah Penentuan Lokasi Khutbah Jum'at, Membuat jadwal selama masa KKN, Berangkat menuju lokasi Khutbah Jum'at. Faktor pendukung kegiatan ini ialah Kepala Desa memberikan kesempatan untuk dapat mengisi Khutbah Jum'at di semua masjid yang terdapat di Desa Balassuka, dan Kepala Desa memfasilitasi kendaraan roda dua milik dinas untuk transportasi mahasiswa.

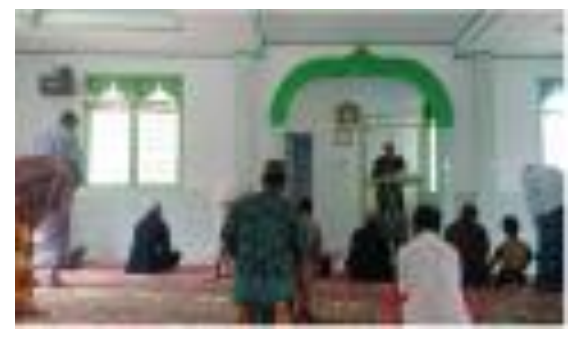

Gambar 1.7. Khutbah Jumat

Hasil Kegiatan: kegiatan khutbah jum'at terlaksana dengan baik dengan terbukanya semua masjid untuk diisi sebagai khatib jum'at, di antara masjid binaan: Masjid Nurul Yaqin Sapohiring; Masjid Nurul Iman Bentengia; Masjid

\footnotetext{
${ }^{11}$ Pambudi, R. Kontribusi Khutbah Jum'at Terhadap Perilaku Keagamaan Masyarakat (Studi kasus di Dusun 1 dan Dusun 2 Desa Balerejo Kecamatan Batanghari Kabupaten Lampung Timur). (Doctoral dissertation, IAIN Metro, 2019).
} 
Baiturrahman Benga; Masjid Nurul Amin Lembang Teko; Masjid Babussalam Lebbasa; Masjid Baitussalam Sapiribborong; Masjid Al-Amin Padakka; Masjid Babul Jannah Bongki; dan Masjid Miftahul Khair. Pengalaman menarik ialah Masyarakat sangat berterima kasih kehadiran mahasiswa STIBA untuk khutbah, dan Terkadang ada Jamaah yang meneteskan air mata.

\section{Berantas Buta Huruf Al Qur'an}

Tujuan dan manfaat: mengenalkan masyarakat desa dengan metode Dirosa dan cara membaca al-Qur'an yang baik dan benar sesuai kaidah tajwid. Mengajarkan masyarakat cara membaca al-Qur'an yang baik dan benar. Sejalan dengannya Guswenti melalui hasil penelitiannya menggambarkan bahwa berantas buta huruf al-Qur'an dengan metode Dirosa dapat meningkatkan kemampuan seseorang dalam kemampuan membaca al-Qur'an seperti aspek mengenal dan melafazkan huruf-huruf hijaiah dengan baik dan benar yang sesuai dengan makharajul huruf, dan tajwid. ${ }^{12}$

Rencana pelaksanaan kegiatan dan waktu pelaksanaan: seluruh masjid dan musala di Desa Balassuka setiap hari serta menyesuaikan waktu mahasiswa dan masyarakat. Target jumlah peserta 200 Orang (10 Kelompok). Estimasi anggaran sebesar Rp.1.524.000,-. Sumber dana berasal dari donasi dan kontribusi peserta dirosa. Langkah-langkah kegiatan: Perizinan Berkegiatan, Melakukan sosialisasi, Melaksanakan program. Faktor pendukung kegiatan ini yaitu Perizinan dari pihak pemerintah desa, antusias masyarakat desa Balassuka yang sangat tinggi dan Pengumpulan dana pribadi untuk pembelian snack dan coffee.

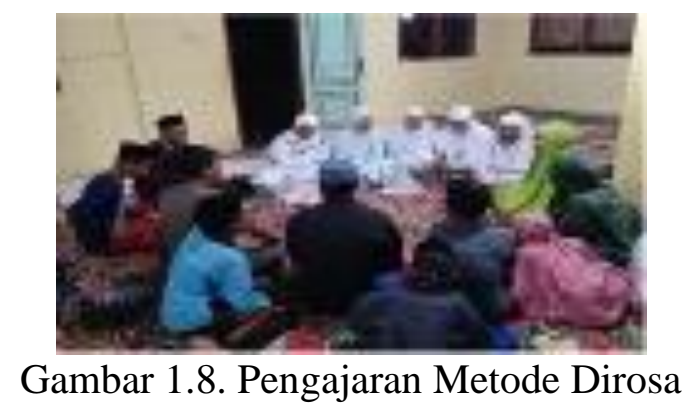

Hasil kegiatan: Kegiatan Pembinaan bacaan Al Qur'an menggunakan metode Dirosa berlangsung di 6 Masjid dan 1 Mushallah binaan, di antaranya: Masjid Nurul Yaqin Sapohiring; Masjid Nurul Iman Bentengia; Masjid Baiturrahman Benga; Masjid Nurul Amin Lembang Teko; Masjid Babussalam Lebbasa; Masjid Baitussalam Sapiribborong; Mushallah Al-Muhajirin Bocci. Hambatan yang dijumpai yaitu Jumlah tenaga pengajar yang kurang, Kendaraan

\footnotetext{
${ }^{12}$ Guswenti, M. Implementasi Metode Dirosa Dalam Pembelajaran Membaca Al-Qur'an Bagi Santri Di Wahdah Islamiyah Bengkulu (Doctoral dissertation, IAIN Bengkulu, 2019).
} 
mahasiswa yang Cuma 2 (dua) buah, Jumlah buku Dirosa dan Papan Tulis Mini yang kurang, dan Kegiatan lain yang cukup padat. Adapun langkah solutif yang ditempuh yakni Membagi waktu mengajar setiap mahasiswa agar mampu menjangkau dua masjid sekaligus dalam sepekan, Bekerjasama dengan pemuda setempat untuk pengantaran dan penjemputan ke atau dari lokasi pengajian Dirosa, dan Menawarkan buku Dirosa untuk dibeli kepada peserta Dirosa. Pengalaman menarik yang dijumpai pada kegiatan ini adalah Mayoritas peserta Dirosa adalah ibu-ibu, Peserta Dirosa sangat bersemangat.

\section{Daily Tahfidz (Tahfidz Harian)}

Tujuan dan manfaat: sebagai sarana penyetoran hafalan sekaligus perbaikan bacaan santri Pesantren Darul Arqam Balassuka. Menambah jumlah setoran hafalan santri dan memperbaiki bacaan atau hafalan yang keliru. Safitri juga demikian yang menyatakan bahwa tujuan dari metode setoran hafalan adalah untuk meningkatkan kemampuan membaca dan menghafal Al-Qur'an santri. ${ }^{13}$

Rencana pelaksanaan kegiatan dan waktu pelaksanaan: Pesantren Darul Arqam Muhammadiyah Balassuka Dilaksanakan setiap Ba'da Subuh, Ashar dan Maghrib. Target dan jumlah peserta ialah Santri Pesantren Darul Arqam Balassuka sebanyak 28. Sumber dana berasal dari pribadi dan donasi. Langkah-langkah kegiatan ini adalah: Musyawarah Penentuan halaqoh, Terlaksanya Tahfidz Weekend. Faktor pendukung kegiatan ini adalah Adanya dukungan dari santri dan pihak pondok untuk menjalankan kegiatan Daily Tahfidz.

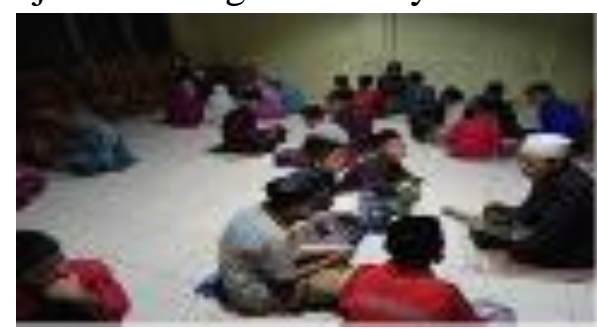

Gambar 1.9. Daily Tahfidz

Hasil kegiatan: kegiatan dilaksanakan di Pesantren Darul Arqam Muhammadiyah Balassuka dengan total 28 santri binaan dari laki-laki maupun perempuan dengan rata-rata sudah menyelesaikan 1 Juz al-Qur'an dalam 1 Bulan. Hambatan yang dijumpai ialah sebagian mahasiswa memiliki tanggung jawab yang cukup padat di luar pesantren sehingga kurang maksimla membina santri yang dibawah tanggungannya, dan Sebagian santri belum lancer membaca al-Qur'an sehingga memperlambat proses penghafalan al-Qur'an. Langkah solutif yaitu

\footnotetext{
${ }^{13}$ Sapittri, D. Pembentukan karakter disiplin dan tanggung jawab melalui program tahfidz AlQur'an juz 30 di kelas IV MI Miftakhul Akhlaqiyah Tambakaji Ngaliyan Semarang 2018/2019 (Doctoral dissertation, UIN Walisongo, 2019).
} 
mahasiswa yang masih berada di pesantren menggantikan posisi mahasiswa yang berkegiatan di luar, dan Perbaikan bacaan dan kelas tambahan tajwid untuk santri. Pengalaman menarik yang dijumpai pada kegiatan ini adalah Ada santri yang mengeluh karena hafalannya tidak bisa terhapal, Santri yang tidak mau pisah dari musyrifnya pada penarikan KKN.

\section{STIBA Mengajar}

Tujuan dan manfaat: Latihan mengajar atau mentrasfer ilmu dari mahasiswa KKN kepada murid-murid MTs dan MA Muhammadiyah Balassuka. Meningkatkan pemahaman para siswa dan siswi dalam masalah agama dan menambah wawasan mereka tentang agama Islam. Oleh karena, pengajaran dilakukan di institusi Muhammadiyah, maka mahasiswa STIBA Makassar harus menyesuaikan dengan corak pendidikan Muhammadiyah. Ali mengatakan bahwa tujuan pendidikan Muhammadiyah lebih mendekati teori pendidikan progresif yang menekankan pada rekonstruksi pengalaman secara terus-menerus sebagai wahana memajukan kehidupan sosial. ${ }^{14}$ Maksud tersebut menghendaki mahasiswa STIBA Makassar untuk melakukan pengajaran ihwal mata pelajaran Agama Islam yang harus mudah dipahami oleh siswa dan memberikan contoh konkret pengalaman keseharian sebagai bekal kontruksi kognitif siswa yang nantinya bermanfaat untuk umat dan bangsa.

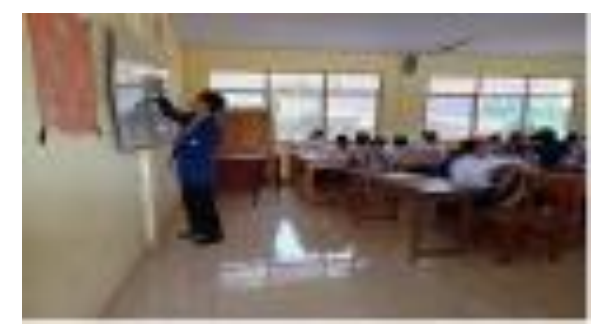

Gambar 2.1. STIBA Mengajar

Rencana pelaksanaan kegiatan dan waktu pelaksanaan: mengikuti jadwal mengajar yang telah ada dan mengambl alih seluruh mata pelajaran keagamaan (Al Qur'an, Hadis, Fiqh, Tajwid, SKI, dll), dan Dilaksanakan setiap hari Sabtu - Kamis. Target dan jumlah peserta ialah Siswa - siswi MTs dan MA Muhammadiyah Balassuka sebanyak 300 orang.

Langkah-langkah kegiatan: Sosialisasi Kepala Sekolah MA dan MTs Muhammadiyah Balassuka, Pengambilan bahan ajar berupa buku cetak di MA dan MTs Muhammadiyah Balassuka, Musyawarah Penentuan Jadwal Mengajar, dan Terlaksananya Belajar Mengajar di MA dan MTs Muhammadiyah Balassuka.

\footnotetext{
${ }^{14}$ Ali, M. Membedah Tujuan Pendidikan Muhammadiyah. Profetika Jurnal Studi Islam, Vol.17, No.01, 2016: h.43-56.
} 
Faktor pendukung pada kegiatan ini adalah Adanya dukungan dari Pihak Sekolah untuk memberikan pengajaran khususnya Agama Islam di MA dan MTs Balassuka.

Hasil kegiatan: Kendala yang dijumpai yaitu Anak-anak ribut dalam proses belajar mengajar, Banyak guru tetap yang tidak aktif sehingga mahasiswa kewalahan mengisi kelas yang tidak ada pengajarnya, Mahasiswa tidak memperhatikan jadwal mengajarnya. Langkah solutifnya yaitu Memberikan sanksi tegas bagi yang main-main di dalam kelas, dan Memberikan semangat agar mahasiswa tetap semangat mengajar.

\section{Pelatihan Bekam dan Ruqyah}

Tujuan dan manfaat: Memperkenalkan dan melatih masyarakat dengan pengobatan sunah. Adapun salah satu manfaat dari terapi bekam adalah dapat menurunkan tekanan darah, sebagaimana penelitian yang dilakukan oleh Amaliyah dan Koto yang menyatakan bahwa terapi bekam dapat menurunkan tekanan darah pada pasien hipertensi. ${ }^{15}$ Adapun juga salah satu dari manfaat ruqyah adalah dapat menurunkan tingkat stress seseorang, sebagaimana penelitian yang dilakukan oleh Komala yang menyatakan bahwa berperan dalam menurunkan gejala-gejala stres bagi penderita gangguan stres. ${ }^{16}$

Rencana pelaksanaan kegiatan dan waktu pelaksanaan: Ahad, 09 Februari 2020 Pukul 09.00 - 14.30 di Masjid Baiturrahim Kelurahan Tamaona Kecamatan Tombolo Pao. Target dan jumlah peserta Masyarakat Kecamatan Tombolo Pao sebanyak 300 Orang. Estimasi anggaran kegiatan sebanyak Rp 1.000.000,-. Sumber dana berasal dari Donasi dan Proposal.

Langkah-langkah kegiatan: Musyawarah Persiapan Pelaksanaan Pelatihan Ruqyah dan Bekam, Konsultasi dengan pihak pemerintah terkait konsep kegiatan, Sosialisasi Kegiatan ke masyarakat berupa penyebaran pamflet ke masjid-masjid, dan Terlaksananya kegiatan Pelatihan Ruqyah dan Bekam. Faktor pendukung kegiatan ini adalah adanya antusias masyarakat dalam menghadiri kegiatan dan dukungan dari pihak pemerintah.

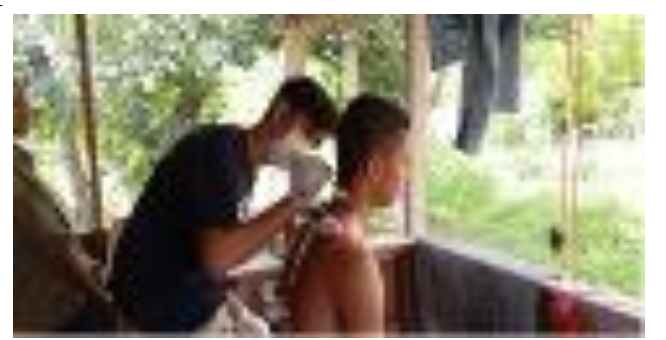

Gambar 2.2. Pelatihan Bekam

\footnotetext{
${ }^{15}$ Amaliyah, H., \& Koto, Y. Terapi Bekam Terhadap Penurunan Tekanan Darah. Jurnal Ilmiah Ilmu Keperawatan Indonesia, Vol.8, No.01, 2018: h.394-400.

${ }^{16}$ Komala, K. Terapi Ruqyah sebagai Upaya Penyembuhan Gangguan Stres: Studi Kasus di Rehab Hati Bandung, Jl. Emong No. 9, Burangrang, Lengkong, Bandung (Doctoral dissertation, UIN Sunan Gunung Djati Bandung, 2017).
} 
Hasil kegiatan: Kegiatan terlaksana dengan baik dan dihari oleh tokoh masyarakat khususnya tokoh-tokoh perempuan dari setiap desa di Kecamatan Tombolo Pao. Hambatan yang ditemui berupa Kurangnya mobilisasi untuk para peserta kegiatan sehingga memperlambat jalannya kegiatan, dan Gangguan teknis di LCD Pemateri. Tindakan solutif yang ditempuh yakni Menyebarluaskan info kegiatan melalui media sosial dan pamflet, dan Gladi acara sebelum dimulai. Pengalaman menarik yang dijumpai pada kegaiatan ini adalah Terdapat pasien yang kerasukan pada saat diruqyah massal.

\section{Pelatihan Penyelenggaraan Jenazah (PPJ)}

Tujuan dan manfaat: Memperkenalkan masyarakat desa tentang cara menyelenggarakan jenazah yang benar dan sesuai sunah. Wawasan baru bagi masyarakat sekaligus kesempatan untuk bertanya pada masalah-masalah seputar jenazah dan penyelenggaraannya. Hasil dari kegiatan ini juga diharapkan sejalan dengan hasil pelatihan penyelenggaraan jenazah yang dilaksanakan oleh Pulungan, dkk., yakni peserta pelatihan memiliki peningkatan kemampuan tidak saja secara teoritis tapi juga praktis dalam pengurusan jenazah. ${ }^{17}$

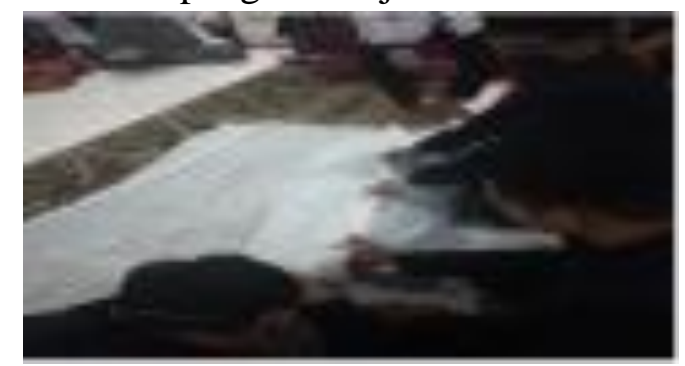

Gambar 2.3. Pelatihan Penyelenggaraan Jenazah

Rencana pelaksanaan kegiatan dan Waktu pelaksanaan: Mengundang imam-imam dari setiap dusun, Rabu, 12 Februari 2020 Pukul 16.10 - 17.00 di Masjid Nurul Yaqin Sapohiring. Target dan jumlah peserta ialah seluruh masyarakat dan tokoh-tokoh agama sebanyak 120 Orang. Estimasi anggaran sebesar Rp. 1.000.000,-. Sumber dana berasal dari donasi dan pribadi.

Langkah-langkah kegiatan: Musyawarah Persiapan Pelaksanaan Pelatihan Penyelenggaraan Jenazah, Konsultasi dengan pihak pemerintah terkait konsep kegiatan, dan Terlaksananya kegiatan Pelatihan Penyelenggaraan Jenazah. Faktor pendukung kegiatan ini adalah Adanya antusias masyarakat dalam menghadiri kegiatan dan dukungan dari pihak pemerintah.

\footnotetext{
${ }^{17}$ Pulungan, S., Sahliah, S., \& Sarudin, S. Peningkatan Keterampilan Pengurusan Jenazah di MTs Ulumul Quran Medan. QALAMUNA: Jurnal Pendidikan, Sosial, dan Agama, Vol.12, No.01, 2020: h.25-35.
} 
Hasil kegiatan: kegiatan dilaksanakan di Masjid Nurul yaqin Sapohiring dan berjalan dengan lancer serta antusias masyarakat yang cukup tinggi. Hambatan yang dijumpai ialah sebagian masyarakat masih termakan oleh mitos dan takut hadir, Mayoritas peserta adalah perempuan, dan Masjid Kurang luas untuk menampung seluruh peserta. Tindakan solutif berupa Perlu penyuluhan dan sosialisasi yang lebih baik lagi, Undangan khusus untuk kaum pria, dan Mencari masjid yang lebih luas lagi. Pengalaman menarik yang dijumpai dalam kegiatan ini adalah pertama kalinya membawakan materi terkait penyelenggaraan jenazah.

\section{Festival Santri}

Tujuan dan manfaat: mengukur kemampuan para santri sekaligus silaturrahim bagi para santri dan pembina dari berbagai TPA Se Kecamatan Tombolo Pao, dan juga sebagai Sarana silaturahmi bagi peserta dan Pembina TPA. Mulasari, dkk., juga mengatakan bahwa festival santri bertujuan untuk melatih keberanian anak di usia dini, sehingga dapat menjadi generasi yang cerdas dan berwawasan Islami. ${ }^{18}$

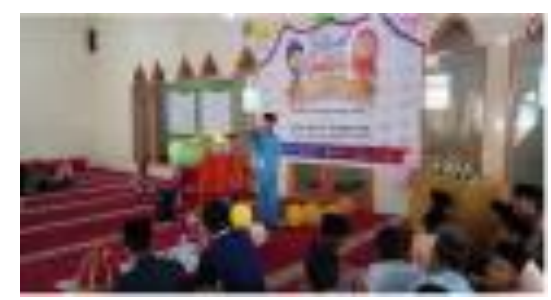

Gambar 2.4. Festival Santri

Rencana pelaksanaan kegiatan dan Waktu pelaksanaan: Ahad - Selasa, 16 17 Februari 2020 di Masjid Baiturrahim Kelurahan Tamaona. Target dan jumlah peserta ialah santri TKA/TPA Se-Desa Balassuka sebanyak 200 Orang. Estimasi anggaran kegiatan sebanyak Rp. 5.000.000,- yang bersumber dari donasi dan proposal.

Langkah-langkah kegiatan: Musyawarah Persiapan Pelaksanaan Festival Santri, Konsultasi dengan pihak pemerintah terkait konsep kegiatan, Pembuatan Konsep kegiatan, Pembuatan Formulir Kegiatan, Pembukaan Pendaftaran. Faktor pendukung ialah adanya antusias masyarakat khususnya santri TKA/TPA dalam menghadiri kegiatan dan dukungan dari pihak pemerintah.

Hasil kegiatan: Berlangsung dengan lancar dan dibuka langsung oleh Bapak Camat Tombolo Pao. Hambatan yang dijumpai ialah Jarak lokasi kegiatan cukup jauh dari desa Balassuka dan Waktu persiapan dan sosialisasi kegiatan cukup

\footnotetext{
${ }^{18}$ Mulasari, S. A., Wibowo, M. W. D., Irjayanti, A., \& Nurmalasari, E. Peningkatan Sumberdaya Manusia Melalui Gedangsari Festival. BERDIKARI: Jurnal Inovasi dan Penerapan Ipteks, Vol.7, No.1, 2019: h.90-97.
} 
singkat. Tindakan solutif berupa Cukup sebagian yang hadir sesuai kebutuhan kegiatan penjurian, dan tambahan waktu beberapa hari sebelum pembukaan. Pengalaman menarik yang dijumpai yaitu Pertama kalinya mengadakan Festival Santri.

\section{Mabit Akbar Pemuda}

Tujuan dan manfaat: Silaturrahim bersama pemuda desa Balassuka, khususnya bagi siswa dan siswi MTs dan MA Muhammadiyah Balassuka sekaligus memberikan arahan dan motivasi untuk menjadi pemuda pembawa perubahan. Saran silaturahmi sekaligus berbagi pengetahuan keagamaan kepada Pemuda Desa Balassuka. Arya juga mengemukakan bahwa tujuan dari MABIT (malam bina iman dan takwa) adalah suatu upaya dalam meningkatkan sikap/perilaku individu untuk mengarah kepada peningkatan yang lebih baik agar menjadi insan yang memiliki sikap/perilaku yang cerdas Spritual, Emosional dan Intelektual. ${ }^{19}$

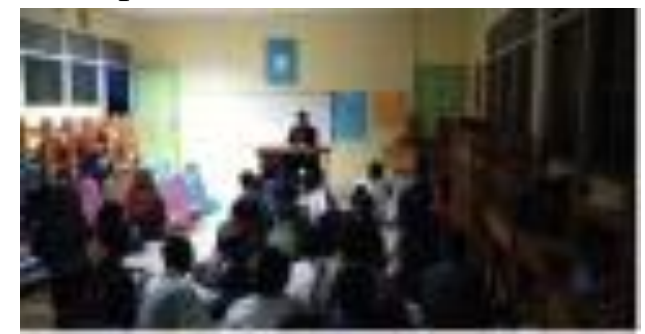

Gambar 2.5. Mabit Akbar Pemuda

Rencana pelaksanaan kegiatan dan Waktu pelaksanaan: Kamis, 13 Februari 2020 Pukul 14.00 - 15.30 di Aula MTs Muhammadiyah Balassuka. Target dan jumlah peserta ialah Pemuda dan Remaja sebanyak 100 orang. Estimasi anggaran kegiatan sebanyak Rp. 500.000,- yang bersumber dari kontribusi peserta.

Langkah-langkah kegiatan: Permintaan dari pihak pondok pesantren, Musyawarah Persiapan Mabit Bersama, Sosialisasi ke Pemuda Desa Balassuka, Terlaksananya Kegiatan Mabit Bersama. Faktor pendukung kegiatan ini yaitu Adanya antusias dari pemuda untuk menghadiri kegiatan, adanya kerja sama dari teman-teman IPM Cabang Balassuka.

Hasil kegiatan: Berlangsung dengan lancar atas kerjasama organisasi Muhammadiyah setempat. Hambatan yang dijumpai ialah Fasilitas penginapan untuk peserta yang kurang memadai, Jarak lokasi berjauhan dari rumah sebgian siswa/i, dan Tidak adanya hijab pembatas antara peserta laki-laki dan perempuan. Tindakan solutif berupa Pemanfaatna kelas sebagai tempat bermalam, Saling menjemput sesama siswa atau siswi, dan Pemisahan Tempat duduk laki-laki dan

${ }^{19}$ Arya, H. Pelaksanaan Pembinaan Akhlak Melalui Kegiatan Mabit Di Sekolah Menengah Pertama Islam Terpadu Bina Insani Kayuagung Oki (Doctoral dissertation, UIN Raden Fatah Palembang, 2018). 
WAHATUL MUJTAMA': Jurnal Pengabdian Masyarakat

Vol. 01, No. 1 (2020) : Hal. 90-115

Website: https://journal.stiba.ac.id

perempuan. Pengalaman menarik yang dijumpai adalah Berkumpul Bersama pemuda Desa Balassuka, saling berkenalan dan bercerita bersama.

\section{Silaturahmi Akbar}

Tujuan dan manfaat: Sebagai bentuk perpisahan dan silaturrahim untuk seluruh peserta Dirosa dan warga desa Balassuka bersama mahasiswa KKN STIBA. Saran silaturahmi sekaligus penutup program KKN.

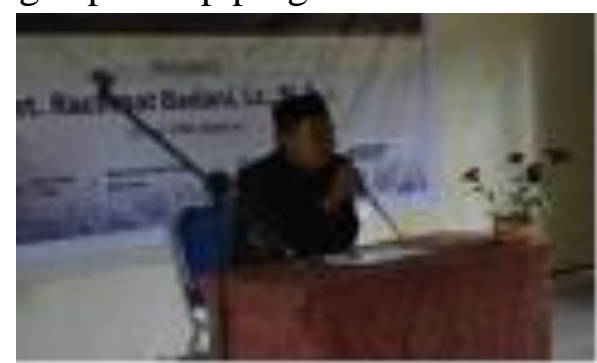

Gambar 2.6. Silaturahmi Akbar

Rencana pelaksanaan kegiatan dan Waktu pelaksanaan: Kamis, 20 Februari 2020 Pukul 14.00 - 17.30 di Aula MA Muhammadiyah Balassuka. Target dan jumlah peserta ialah Masyarakat Umum sebanyak 200 orang. Estimasi anggaran kegiatan sebanyak Rp. 500.000,- yang bersumber dari donasi dan pribadi.

Langkah-langkah kegiatan: Musyawarah Persiapan Silaturahmi Akbar, Konsultasi dengan pihak pemerintah terkait konsep kegiatan, Sosialisasi Kegiatan ke masyarakat berupa penyebaran pamflet ke masjid-masjid dan undangan ke mejelis-majelis ta'lim dan peserta DIROSA, Terlaksananya kegiatan Silaturahmi Akbar. Faktor pendukung kegiatan ini yaitu Adanya dukungan pemerintah dalam pelaksanaan kegiatan Silaturahmi Akbar.

Hasil kegiatan: Berlangsung dengan lancar dan dihadiri oleh ibu-ibu dan bapak-bapak dari seluruh Desa Se Balassuka. Hambatan yang dijumpai ialah Cuaca Hujan dan berangin kencang dan Jalanan licin. Tindakan solutif berupa Pasrah akan kehendak Allah, dan Mengingatkan peserta untuk hadir. Pengalaman menarik yang dijumpai adalah Pertama kali membuat acara besar.

\section{REFLEKSI}

\section{Gambaran Masyarakat Balassuka Sebelum Mengikuti Program KKN}

- Masih kurangnya kesadaraan masyarakat tentang kewajiban sholat berjamaah dimasjid tepat waktu terutama pada saat musim tanam dan musim panen

- Masih kurangnya pemahaman masyarakat tentang persoalan zakat terutama zakat pertanian dan zakat mal

- Beberapa masyarakat masih melakukan praktik-praktik kesyirikan seperti meminta dan berdoa dikuburan, menyembelih hewan kemudian diperuntukkan untuk sesajen dan lain sebagainnya

- Masih kurangnya pemahaman masyarakat tentang proses penyelenggaraan 
jenazah yang sesuai dengan tuntunan rasulullah

- Masih banyak masyarakat yang belum mampu menyebutkan huruf-huruf Alquran dengan baik dan benar

- Masih banyak anak-anak yang hanya bermain game android saja dan kurang bimbingan.

- Masih kurangnya kesadaran masyarakat akan pentingnya menuntut ilmu agama.

- Masih banyak masyarakat yang masih berpegang teguh terhadap kepercayaan nenek moyangnya tanpa menghiraukan norma-norma agama

\section{Gambaran Masyarakat Balassuka Setelah Mengikuti Program KKN}

- Masyarakat mulai paham tentang pentingnya sholat berjamaah di masjid

- Sedikit demi sedikit masrakat sudah mulai paham dan meninggalkan perkaraperkara kesyirikan

- masyarakat mulai paham tentang proses penyelenggaraan jenazah yang sesuai dengan tuntunan rasulullah

- sudah banyak masyarakat yang sudah mampu menyebutkan huruf-huruf Alquran dengan baik dan benar baik anak-anak, remaja, dan orang dewasa menggunakan metode TPA, dirosa dan tahsin

- dengan adanya program TPA, bermain sambil belajar, dan kegiatan-kegiatan lainya sehingga anak-anak yang dulunya hanya bermain game android saja sekarang mulai teralih fokuskan ke kegiatan yang lebih bermanfaat

- Dengan adanya program taklim pekanan, kultum subuhdan program pembacaan kitab setiap zuhur kini masyarakat mulai paham akan pentingnya menuntut ilmu agama.

\section{KESIMPULAN}

Tujuan dari KKN STIBA Makassar di Desa Balassuka secara umum adalah untuk mengamalkan tri dharma perguruan tinggi pada pilar pengabdian masyarakat. Secara khusus dimaksudkan agar terjadi peningkatan pemahaman keislaman, keterampilan baca tulis al-Qur'an, dan semangat mempelajari dan mengamalkan ilmu agama Islam berdasarkan pemahaman salafussaleh atau ahlussunah waljama'ah. Hasil kegiatan KKN STIBA Makassar angkatan III di Desa Balassuka menunjukkan bahwa masyarakat dan pemerintah setempat sangat antusias dan berterima kasih atas manfaat yang diperoleh dari pelaksanaan program-program kerja mahasiswa KKN di Desa Balassuka. Dari sisi pengetahuan, masyarakat mengalami perkembangan wawasan keislaman. Dari sisi keterampilan perubahan dirasakan pada pelafalan makhraj dan tajwid dalam pembacaan al-Qur'an. Dari sisi afeksi, masyarakat mulai sadar dan bersemangat dalam melaksanakan ibadah yang didasari oleh ilmu agama yang baik dan benar. 


\section{DAFTAR PUSTAKA}

Ali, M. (2016). Membedah Tujuan Pendidikan Muhammadiyah. Profetika Jurnal Studi Islam, 17(01), 43-56.

Amaliyah, H., \& Koto, Y. (2018). Terapi Bekam Terhadap Penurunan Tekanan Darah. Jurnal Ilmiah Ilmu Keperawatan Indonesia, 8(01), 394-400.

ARYA, H. (2018). Pelaksanaan Pembinaan Akhlak Melalui Kegiatan Mabit di Sekolah Menengah Pertama Islam Terpadu Bina Insani Kayuagung OKI (Doctoral Dissertation, Uin Raden Fatah Palembang).

Dangnga, M. S. Peran Majelis Taklim Nurul Huda Dalam Peningkatan Pengamalan Keagamaan Masyarakat Kelurahan Palanro Kabupaten Barru.

Fajri, Z. (2015). Manfaat Pelaksanaan Program Kegiatan Kuliah Kerja Nyata (Kkn) Mahasiswa (Suatu Penelitian Di Kecamatan Meurah Dua Pidie Jaya). ETD Unsyiah.

Gustina, D., Adbullah, I., \& Sofino, S. (2019). Pemberdayaan Masyarakat Melalui Kegiatan Kuliah Kerja Nyata (KKN) Mahasiswa Universitas Bengkulu Periode 86 Tahun 2018 di Desa Tebat Monok Kabupaten Kepahiang. Journal Of Lifelong Learning, Vol.2, No.1

Guswenti, M. (2019). Implementasi Metode Dirosa Dalam Pembelajaran Membaca Al-Qur'an Bagi Santri Di Wahdah Islamiyah Bengkulu (Doctoral dissertation, IAIN BENGKULU).

Handayani, H. (2017). Aktivitas Program Jum'at Ibadah dalam Pembentukan Akhlak Al-Karimah di Desa Mardekaya Kecamatan Bajeng Kabupaen Gowa (Doctoral dissertation, Universitas Islam Negeri Alauddin Makassar).

Indrawan, I., Sukri, A., \& US, K. A. (2019). Silaturahmi Pemimpin Terhadap Bawahan dalam Sistem Manajemen Pendidikan Islam. Jurnal Al-Afkar, Vol.7, No.1

Iswadi, I. (2019). Penguatan Nilai Keagamaan Bagi Kelompok Pengajian Remaja di Kelurahan Tanah Sirah Piai Nan XX. Alfuad: Jurnal Sosial Keagamaan, Vol.3, No.2, h:76-84.

Komala, K. (2017). Terapi ruqyah sebagai upaya penyembuhan gangguan stres: studi kasus di Rehab Hati Bandung, Jl. Emong No. 9, Burangrang, Lengkong, Bandung (Doctoral dissertation, UIN Sunan Gunung Djati Bandung). 
WAHATUL MUJTAMA': Jurnal Pengabdian Masyarakat

Vol. 01, No. 1 (2020) : Hal. 90-115

Website: https://journal.stiba.ac.id

Mulasari, S. A., Fatihah, A. N., \& Setiawan, A. (2019). Upaya Penanggulangan Rentenir Oleh Kuliah Kerja Nyata Universitas Ahmad Dahlan di Dusun Klepu, Nglegi, Patuk, Gunungkidul, DI Yogyakarta 2018. Jurnal Pemberdayaan: Publikasi Hasil Pengabdian Kepada Masyarakat, Vol.2, No.3, h:479-486.

Mulasari, S. A., Wibowo, M. W. D., Irjayanti, A., \& Nurmalasari, E. (2019). Peningkatan Sumberdaya Manusia Melalui Gedangsari Festival. BERDIKARI: Jurnal Inovasi dan Penerapan Ipteks, Vol.7, No.1, h:90-97.

Nurhayati, S. (2017). Tanggapan Masyarakat Terhadap Kultum ba'da Subuh Hubungannya dengan Motivasi Mereka dalam Mengikuti Shalat Berjamaah di Masjid: Penelitian di Masjid Jami Nurul Huda Cirabak RT 005 RW 002 Dusun Cibingbin Rajadesa Ciamis (Doctoral dissertation, UIN Sunan Gunung Djati Bandung).

Pambudi, R. (2019). Kontribusi Khutbah Jum'at Terhadap Perilaku Keagamaan Masyarakat (Studi kasus di Dusun 1 dan Dusun 2 Desa Balerejo Kecamatan Batanghari Kabupaten Lampung Timur) (Doctoral dissertation, IAIN Metro).

Perdana, A., Holilulloh, M., Holilulloh, M. S., \& Nurmalisa, Y. (2013). Pengaruh Pelaksanaan Kuliah Kerja Nyata Terhadap Keterampilan Sosial Mahasiswa Program Studi PPKN. Jurnal Kultur Demokrasi, Vol.1, No.7.

Pulungan, S., Sahliah, S., \& Sarudin, S. (2020). Peningkatan Keterampilan Pengurusan Jenazah di MTs Ulumul Quran Medan. QALAMUNA: Jurnal Pendidikan, Sosial, dan Agama, Vol.12, No.1, h:25-35.

Sapittri, D. (2019). Pembentukan Karakter Disiplin dan Tanggung Jawab Melalui Program Tahfidz Al-Qur'an Juz 30 di Kelas IV MI Miftakhul Akhlaqiyah Tambakaji Ngaliyan Semarang 2018/2019 (Doctoral dissertation, UIN Walisongo).

Sulandari, S., Wijayanti, M., \& Pornamasari, R. D. (2017). Keterlibatan Lansia dalam Pengajian: Manfaat Spiritual, Sosial, dan Psikologis. Indigenous: Jurnal Ilmiah Psikologi, Vol.1, No.2 